Agric. Biol. Chem, 41 (2), 235 238, 1977

\title{
Cellulase Production in Semisolid Cultures of Trichoderma viride
}

\author{
Leonora C. Vilela, Angelo R. Torillo, Alice T. de OCAmpo \\ and Ernesto J. del RosArIo* \\ Biological Research Center, National Institute of Science and Technology, \\ Manila, Philippines \\ *Department of Chemistry, University of the Philippines at Los Baños College, \\ Laguna, Philippines
}

Received June 15, 1976

\begin{abstract}
Cellulase was produced by Trichoderma viride in semisolid cultures of rice bran, rice straw and rice hulls. $T$. viride QM 9414 generally produced higher cellulolytic activity on CM-cellulose $\left(C_{x}\right.$ activity) using rice bran-rice hull mixture $(2: 1 \mathrm{w} / \mathrm{w})$ as substrate compared to strains ITCC 1433 and $D$ 4014. It showed higher $C_{z}$ activity on rice bran-rice straw mixtures than on rice bran-rice hull mixtures. Maximal extraction of the enzyme from mold bran was obtained with $0.05 \mathrm{M}$ sodium citrate buffer, $\mathrm{pH} 3.5$.
\end{abstract}

Cellulase has found a wide range of applications, especially in the saccharification of waste cellulose into glucose. ${ }^{1 \sim 3}$ \} The latter may be utilized directly or as a fermentation feedstock in the production of singlecell protein, alcohol and other chemicals. However, enzyme use is generally limited by high costs of producing the enzyme. Two methods, namely submerged fermentation and semisolid culture, are employed for cellulase production. ${ }^{4)}$ The former method is favored in industrialized countries since culture conditions can be controlled more easily. The latter method, although labor-intensive and less subject to automatic control, does not need extensive capitalization and is readily applicable in developing countries.

The present paper deals with the production of cellulase by Trichoderma viride, a mold which produces highly active cellulase. ${ }^{4)}$ Three strains of $T$. viride were cultured on semisolid cultures of rice bran, rice hulls and rice straw. The effect of culturing time, inoculum age and substrate composition of cellulase production by the mold was studied. Enzyme activity and recovery in the filtrates were evaluated in terms of the $\mathrm{pH}$, molarity and volume of the extracting buffer.

\section{MATERIALS AND METHODS}

Substrate and fungus. Rice straw and rice hulls were obtained from Calauan, Laguna. Rice bran was purchased from a Manila store and a mixture of rice bran and rice hulls $(2: 1 \mathrm{w} / \mathrm{w})$ was bought from a Calauan rice mill. Both rice bran samples contained $50 \sim 100$ mesh particles and were used directly as culture medium. The rice straw and hulls were ground in a Wiley mill to 40 -mesh size.

Trichoderma viride QM 9414 and ITCC 1433 were obtained from the U.S. Army Natick Laboratories, Mass., U. S. A. and the Mycology Division of IARI, New Delhi, India, respectively. $T$. viride D 4014 was given by Dr. Flordeliz R. Uyenco of the U.P. Natural Science Center, Diliman, Quezon City. Stock cultures of the fungus were maintained on potato dextrose agar (PDA) at room temperature $\left(29 \pm 1^{\circ} \mathrm{C}\right)$ and transferred every month. Fresh cultures were used in the experiment.

Cellulase production. Ten grams of the medium were thoroughly mixed, using a glass stirring rod, with $8 \mathrm{ml}$ of tap water in a flat rum bottle. The wetted medium was autoclaved at 15 psi steam pressure for $30 \mathrm{~min}$, allowed to cool and aseptically inoculated with the fungus. A $1.5 \times 10^{7}$ spores/cc size of inoculum was used in the experiments. Culturing was done at room temperature for 15 days. In the determination of the time dependence of cellulase production, each fungal strain was inoculated into the flat bottles containing the rice bran-hull mixture $(2: 1$ $\mathrm{w} / \mathrm{w}$ ) and for each enzyme assay $2 \sim 4$ bottles were sampled. For the studies on enzyme extraction with citrate buffer of varying molarity or $\mathrm{pH}$, pure rice bran was used as culture medium. 
Fifty $\mathrm{ml}$ of $0.05 \mathrm{M}$ sodium citrate buffer, $\mathrm{pH} 5.0$, was used to extract the enzyme from each $10 \mathrm{~g}$ sample of the mold bran. The enzyme extract was filtered through glass wool, centrifuged for $10 \mathrm{~min}$ at 2500 $\mathrm{rpm}$ and the supernatant was assayed directly for $\mathrm{C}_{\mathbf{x}}$ activity.

Analytical procedures. Cellulase $\left(\mathrm{C}_{\mathbf{x}}\right)$ activity was determined by measuring the reducing sugars produced from carboxymethyl-cellulose. ${ }^{4}$ The amount of reducing sugars formed (expressed as glucose) was determined using the Schaffer-Somogyi method., ${ }^{5}$ One unit of $C_{x}$ activity is defined as an amount of enzyme which produces $4 \mathrm{mg}$ of reducing sugars from CM-cellulose in one hour at $50^{\circ} \mathrm{C}$.

Measurement and adjustment of $\mathrm{pH}$ were done with a Radiometer Model $26 \mathrm{pH}$ meter.

\section{RESULTS AND DISCUSSION}

Plots of cellulase $\left(\mathrm{C}_{\mathrm{x}}\right)$ activity versus time for the three strains of Trichoderma viride cultured at $29^{\circ} \mathrm{C}$ on rice-bran hull mixture $(2: 1, w / w)$ are given in Figs. 1, 2 and 3, which correspond to six-eight-and ten-day old inocula, respectively. Each point in the figures was obtained from two separate trials, each trial corresponding to a minimum of duplicate determinations. It can be seen that the QM

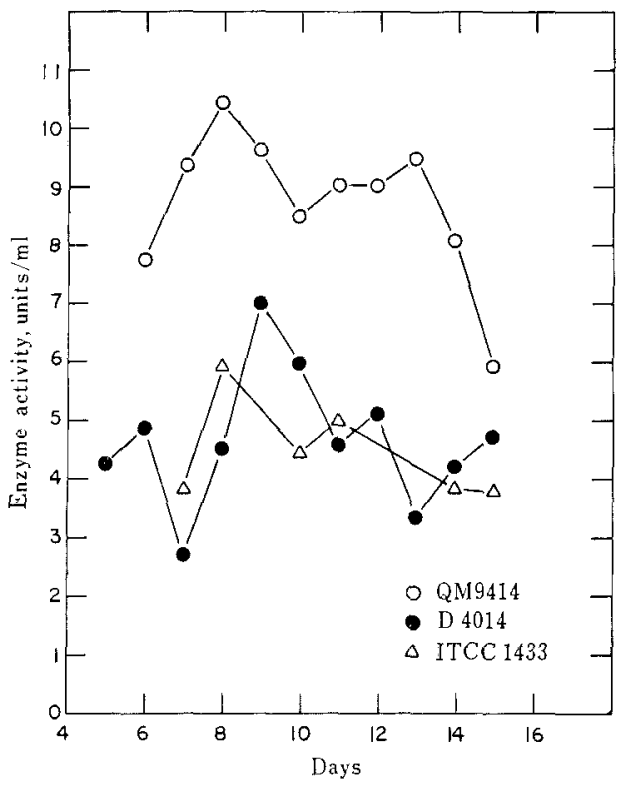

Fig. 1. Activity-time Profiles of Cellulase Productjon by Three Strains of Trichoderma viride Using Six-day Old Inocula.

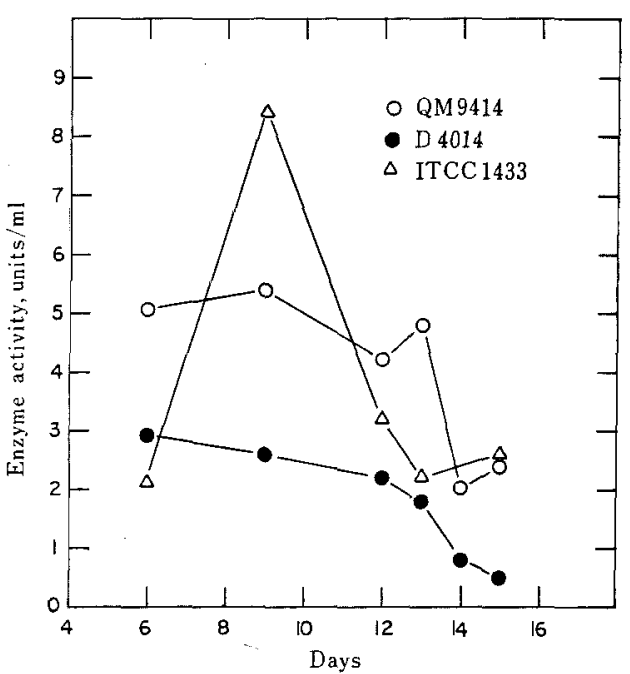

FIG. 2. Activity-time Profiles of Cellulase Production by Three Strains of $T$. viride Using Eight-day Inocula.

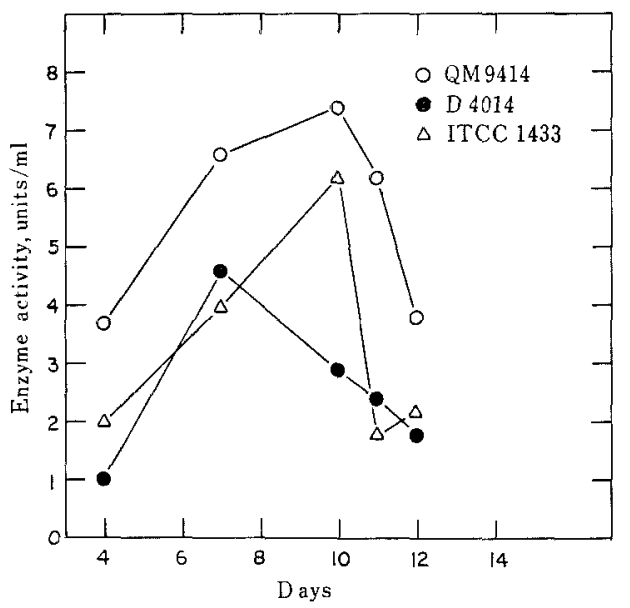

FIg. 3. Activity-time Profiles of Cellulase Production by Three Strains of $T$. viride Using Ten-day Old Inocula.

9414 strain produced the most active cellulase for the six-day and ten-day old slants while the ITCC strain gave the most active enzyme for the eight-day inoculum. The peak of enzyme production for the three strains occurred between the seventh and tenth day of culturing regardless of age of inoculum. The sixday old QM 9414 inoculum gave the highest overall enzyme activity of $10.3 \mathrm{C}_{\mathrm{x}}$ units $/ \mathrm{ml}$ after eight days of incubation.

The effect of substrate composition on cellu- 


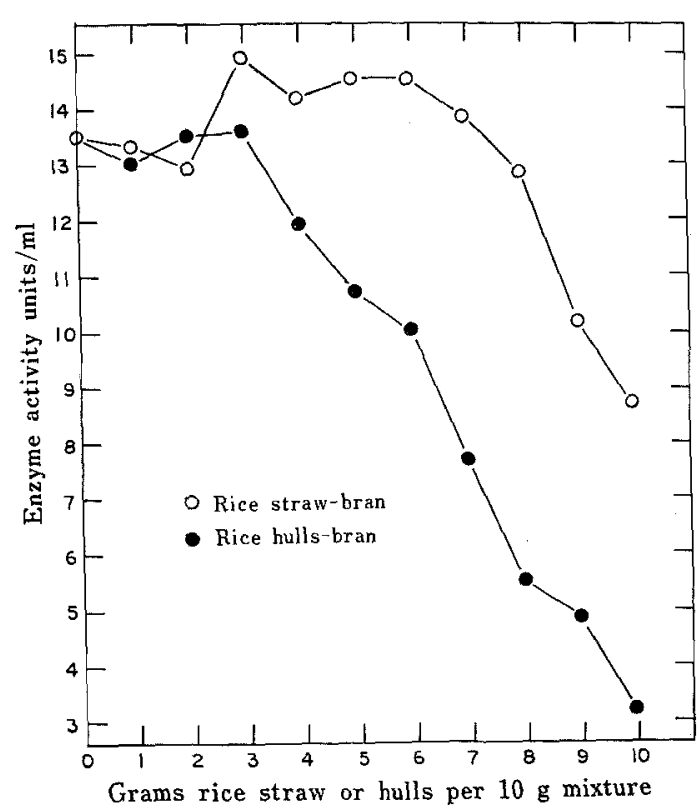

FIG. 4. Effect of Substrate Composition on Cellulase Activity of $T$. viride QM 9414.

lase production of $T$. viride QM 9414 is shown in Fig. 4. A six-day old inoculum was used and the enzyme was extracted with $0.05 \mathrm{M}$ sodium citrate, $\mathrm{pH} 5.0$, after eight days of incubation at $29^{\circ} \mathrm{C}$. Each point in the figure corresponds to three separate determinations and has an estimated uncertainty of $12 \%$. Figure 4 shows that maximum cellulase production was obtained from $30 \%$ rice strawbran mixture. Mixtures of rice hulls and bran served nearly as good a substrate as pure rice bran or corresponding rice straw-bran mixtures up to a composition of $30 \%$ rice hulls. Above this level, the rice-hull-bran mixtures gave much lower enzyme yields compared to corresponding rice straw-bran mixtures. Rice straw was superior to rice hulls but inferior to rice bran as substrate. However, for economic reasons rice straw-bran mixtures up to $80 \%$ straw level may be suitably used for enzyme production instead of pure rice bran. Alternatively, a $33 \%$ rice hullbran mixture, which was used in obtaining the activity-time profiles and is available commercially, may be used as fungal nutrient.

The effect of molarity of the sodium citrate

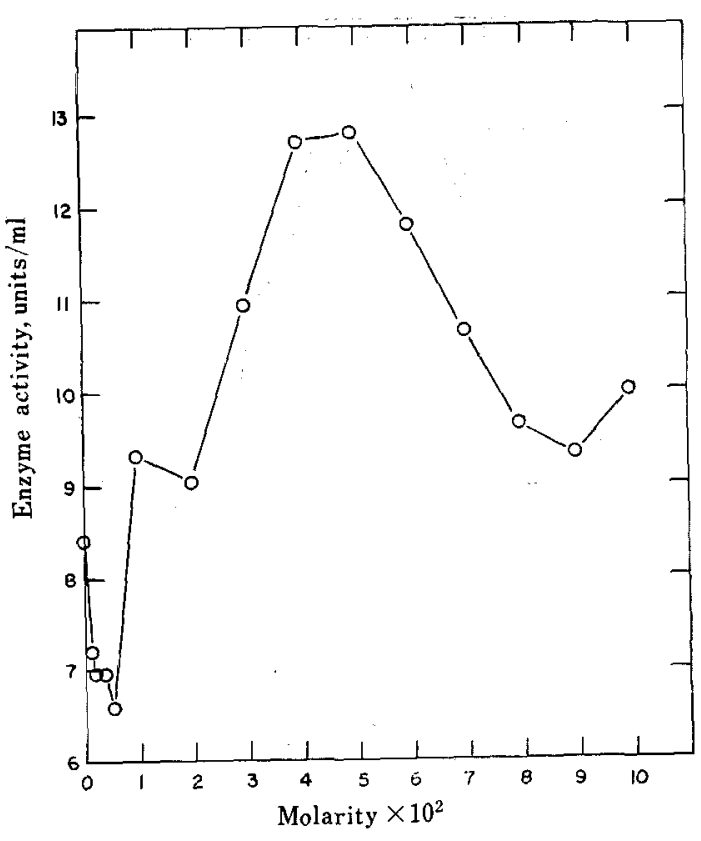

Fig. 5. Cellulase Activity of Extracts from Rice Bran Cultures of T. viride QM 9414 as a Function of Molarity of the Extracting Citrate Buffer.

buffer, $\mathrm{pH}$ 5.0, which was used to extract cellulase from the semisolid culture of $T$. viride, on enzyme activity is illustrated in Fig. 5. Each point in the figure was averaged from a minimum of three trials and the point for zero molarity applies to distilled water whose $\mathrm{pH}$ had been adjusted to 5.0. It is seen that $0.05 \mathrm{M}$ citrate buffer maximally extracted enzyme from the mold bran. Although buffer concentrations higher than $0.1 \mathrm{M}$, which were not employed, could give better enzyme yields, higher attendant costs of preparing the buffer have to be considered. The presence of minima in Fig. 5 is unexplained since several factors could affect enzyme yields such as buffering capacity and ionic strength of the buffer. The $\mathrm{pH}$ of the citrate buffer was found to increase after extraction of the mold bran. This $\mathrm{pH}$ increase was higher at low concentrations of the buffer. It was equal to $1.0 \sim$ $1.6 \mathrm{pH}$ units at concentrations less than or equal to $0.005 \mathrm{M}$ and was less than one $\mathrm{pH}$ unit a higher concentrations.

Values of enzyme activities as a function of $\mathrm{pH}$ of the extracting $0.05 \mathrm{M}$ sodium citrate 


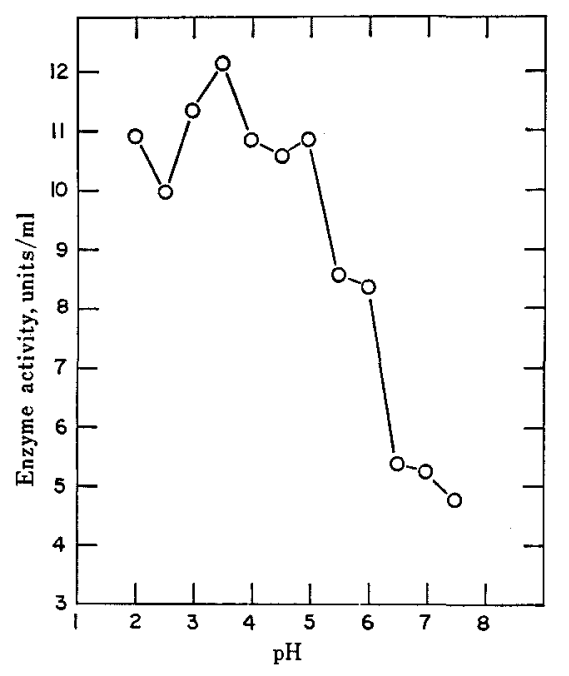

Fig. 6. Cellulase Activity of Extracts from Rice Bran Cultures of $T$. viride QM 9414 as a Function of $\mathrm{pH}$ of the Extracting Citrate Buffer.

buffer are plotted in Fig. 6. Enzyme extraction was maximal at $\mathrm{pH} 3.5$ and decreased substantially at $\mathrm{pH}$ values higher than 5 . The $\mathrm{pH}$ of the buffer increased after extraction of the mold bran except at $\mathrm{pH} 7$ and 7.5 where a $\mathrm{pH}$ decrease was observed. The $\mathrm{pH}$ shift was minimal (0.05) at $\mathrm{pH} 5.5$, which is close to the $\mathrm{p} K$ of the least acidic proton in citric acid, and increased as the $\mathrm{pH}$ deviated from 5.5. It was equal to 1.2 units at $\mathrm{pH} 2$ and -0.7 at $\mathrm{pH}$ 7.5. The results shown in Fig. 6 can be explained in terms of the $\mathrm{pH}$ dependence of the solubility and activity of cellulase.

The activity and recovery of cellulase from the mold bran depends on the volume of the extracting $0.05 \mathrm{M}$ sodium citrate buffer, $\mathrm{pH} 5.0$, as presented in Table I. Enzyme recovery was calculated by dividing the actual volume of enzyme extract by the volume of extracting buffer. The tabulated data were obtained from three separate trials and have an estimated uncertainty of $15 \%$. Enzyme activity per $\mathrm{ml}$ of solution decreased, while recovery increased,
Table I. Cellulase Activity and Recovery FROM Rice Bran CuLtures of Trichoderma viride

\begin{tabular}{ccc}
\hline $\begin{array}{c}\text { Volume of } 0.05 \mathrm{M} \\
\text { sodium citrate } \\
\text { buffer }(\mathrm{pH}) \\
\text { ml } / 10 \mathrm{~g} \text { mold } \\
\text { bran }\end{array}$ & $\begin{array}{c}\text { Enzyme } \\
\text { activity } \\
\mathrm{C}_{\mathbf{x}} \text { units } / \mathrm{ml}\end{array}$ & $\begin{array}{c}\text { Percent } \\
\text { enzyme } \\
\text { recovery }\end{array}$ \\
\hline 30 & 14.3 & 76 \\
40 & 14.4 & 85 \\
50 & 14.2 & 88 \\
60 & 14.0 & 90 \\
70 & 12.9 & 90 \\
80 & 11.2 & 94 \\
90 & 11.7 & 94 \\
$90(3 \times 30)$ & 12.8 & 94 \\
\hline
\end{tabular}

as the volume of the buffer was increased. This observation is expected since more liquid dilutes the enzyme but is more effective in extracting the enzyme from the mold bran. Also given in the table are results from a 3step sequential extraction of the enzyme which are not significantly different from those for the single-step process. The volume of extracting buffer used for the rest of the present study, namely $50 \mathrm{ml}$, is reasonably optimal since a high enzyme activity is obtained in the extract and enzyme recovery is moderately high.

Acknowledgements. This research study was funded by the National Science Development Board (NSDB NIST $7317 \mathrm{En})$. The authors acknowledge the assistance of Dr. Vedasto R. Jose and Miss Cristeta Pontiveros.

\section{REFERENCES}

1) T. K. Ghose and J. A. Kostick, Advan. Chem. Series, 95, 415 (1969).

2) M. Mandels, L. Hontz and J. Nystrom, Biotechnol. Bioeng., 16, 1471 (1974).

3) J. K. Gupta, Y. P. Gupta and N. B. Das, Agric. Biol. Chem., 37, 2657 (1973).

4) M. Mandels and J. Weber, Advan. Chem. Series, 95, 391 (1969).

5) Association of Official Agricultural Chemists, Official Methods of Analysis, Washington, D. C. 1968. 